\title{
The viability of sustained growth by India's MNEs: India's dual economy and constraints from location assets
}

Article

Accepted Version

Narula, R. (2015) The viability of sustained growth by India's MNEs: India's dual economy and constraints from location assets. Management International Review, 55 (2). pp. 191205. ISSN 1861-8901 doi: https://doi.org/10.1007/s11575-0150243-x Available at https://centaur.reading.ac.uk/38243/

It is advisable to refer to the publisher's version if you intend to cite from the work. See Guidance on citing.

To link to this article DOI: http://dx.doi.org/10.1007/s11575-015-0243-x

Publisher: Gabler Verlag

All outputs in CentAUR are protected by Intellectual Property Rights law, including copyright law. Copyright and IPR is retained by the creators or other copyright holders. Terms and conditions for use of this material are defined in the End User Agreement.

www.reading.ac.uk/centaur 
Central Archive at the University of Reading

Reading's research outputs online 


\title{
The viability of sustained growth by India's MNEs: India's dual economy and constraints from location assets
}

\section{Rajneesh Narula}

Forthcoming, Management International Review, 2015

\begin{abstract}
This paper considers the longer-term viability of the internationalization and success of Indian MNEs. We apply the 'dual economy' concept (Lewis 1954), to reconcile the contradictions of the typical emerging economy, where a 'modern' knowledge-intensive economy exists alongside a 'traditional' resource-intensive economy. Each type of economy generates firms with different types of ownership advantages, and hence different types of MNEs and internationalisation patterns. We also highlight the vulnerabilities of a growth-byacquisitions approach. The potential for Indian MNEs to grow requires an understanding of India's dual economy and the constraints from the home country's location advantages, particularly those in its knowledge infrastructure.
\end{abstract}

JEL: F23, F68, O32. 


\section{Introduction}

Any analysis of India potential for growth and development tends to evolve into a discussion of its underlying contradictions (see most recently, Bhagwati and Panagariya 2012 and Drèze and Sen 2013). Such debate has occupied the attention of economists, sociologists and anthropologists for several decades; there is no reason it should not now be joined by those interested in India's MNEs, and their international expansion. Will the future belong to India's seemingly pervasive entrepreneurial cadre, its MNEs in successful high-tech industries, and their unstoppable expansion through global acquisitions? Or will the future of Indian firms be shaped by India's comparative advantage in natural resources, its dependence on low-value, labour-intensive activities, hindered by low productivity firms, institutional inefficiencies and infrastructural bottlenecks?

This paper argues that both are simultaneously true. One of the seminal contributions in development economics builds around the idea that developing countries are 'dual economies' (Lewis 1954, Singer 1970). To paraphrase the Lewisian view somewhat: The key features are a large 'traditional' subsistence (and often informal) sector that reflects a high labour-intensity and a strong dependence on natural resources and agriculture, resting somewhat uneasily alongside a 'modern' urban economy which is engaged in knowledgeintensive, capital- and skills-dependent activities. The 'traditional' sector focuses largely on local needs and when it internationalises it is primarily trade-enhancing, or trade-substituting. The 'modern' economy seeks advanced markets abroad through FDI, and has an international focus. Examining the prospects for the growth of Indian MNEs requires us to acknowledge both these aspects of its economy, as opposed to a singular emphasis on its high-tech sectors. Although the focus in this paper is India and Indian MNEs, these principles are relevant to most DC MNEs. This paper focuses on the subset of nascent MNEs. That is, MNEs which are at an early stage of internationalisation. This distinction is an important one, because as DC MNEs become more experienced, their modus operandi does not greatly differ from those emanating from more advanced economies (Cuervo-Cazurra 2012).

Both traditional and modern sectors can generate MNEs, but of different types, with different motives, and each sector displays different patterns of internationalisation. To put it into the 
context to the eclectic paradigm, the duality of the types of location-specific (L) assets of the home country results in a duality of ownership-specific $(\mathrm{O})$ assets of its firms (and hence its MNEs). It is well-known that the strengths and weaknesses of the $\mathrm{L}$ assets of the home country shape and determine the kinds of $\mathrm{O}$ assets of its firms, and by extension, the $\mathrm{O}$ assets of its MNEs (Narula 2012).

The next section clarifies the different types of $\mathrm{O}$ assets of firms (and MNEs) and helps to explain where the DC MNE's strength comes from, utilising this to highlight the vulnerabilities of such assets for long term growth of firms and their nascent internationalisation. It also examines the potential shortcomings of a growth-by-acquisitions strategy for DC MNEs. The paper proceeds to discuss the concatenation of $\mathrm{L}$ and $\mathrm{O}$ assets, building upon the dual economy construct as a basis for this analysis. It then examines the case of India and the longer-term viability of the internationalization and success of Indian MNEs.

\section{Where do the $O$ assets of DCMNEs come from?}

DC MNEs are no different from MNEs of advanced countries in that they derive from domestic firms in their home country. All firms require the control and use of assets which allow them to generate returns. These are known as firm-specific assets (FSAs) or ownershipspecific (O) assets (these terms are used as synonyms in this paper). The term 'firm-specific' or 'ownership-specific' is intended to make clear that these assets are not legally available to other potential users without prior agreement. When assets are controlled and/or owned by a public organisation (such a government entity) in a specific location and are not exclusive to a particular economic actor but are potentially available to all actors they are termed locationspecific (L) assets (or advantages).

$\mathrm{O}$ assets can be context-specific. Location-bound $\mathrm{O}$ assets allow the firm to generate profits only in a specific location, for instance due to government-induced incentives, such as privileged access to specific natural resources, to capital, or specific infrastructure (e.g., telecoms licenses, petroleum drilling rights). $\mathrm{O}$ assets may also be location-bound because they derive from knowledge of home-country institutions. These assets are not transferable to foreign markets, because establishing 'membership' in business and innovation networks in 
new locations is not costless (Narula 2012). Some O assets are mobile, in that they represent a source of rent generation in other locations.

As discussed elsewhere (Narula 2012, Cuervo-Cazurra 2012), the home country plays a significant role in constraining and defining the kinds of assets an MNE possesses. This is especially so for nascent MNEs, which are firms that have just begun to internationalise. L assets vary considerably between home countries, and as such there are inevitable differences in the early internationalisation of firms from different home countries.

Once past the early stages of internationalisation, differences due to their initial home country conditions become less significant (Rugman 2008). As they become embedded in new locations abroad, the $\mathrm{O}$ assets of MNEs are increasingly influenced by the $\mathrm{L}$ assets of host countries, and the home country may play a lesser role (Meyer et al 2011).

\section{$\underline{\text { On advantages versus assets }}$}

This paper intentionally distinguishes between 'advantage' and 'asset'. 'Advantage' implies - in a similar sense as comparative and absolute advantage - the relative strength of a firm over other firms, or a location over other locations ${ }^{1}$. To conclude that something represents an advantage over something else requires the neoclassical assumption that those making such an evaluation are rational and have perfect information about the alternatives. Such an assumption is clearly unrealistic. A firm rarely has objective information about the (present or future) value of its own assets, and to judge that its assets are superior to a rival's version is even harder. The same is true for location advantages. This is not simply a matter of semantics. 'Advantages' suggests a value judgement; 'assets' do not. An asset may provide an advantage to a firm, or it may not. An advantage may dissipate and simply be an asset, and in different circumstances (or location) an asset may provide an advantage where it hitherto had not. Suffice to say, in a dynamic world, all advantages are temporary, because competitors are expected to imitate and innovate.

By the simple expediency of noting the growth of DC MNEs we can safely conclude that many do indeed possess assets that provide advantages for the purposes of internationalisation, even if we are unclear which assets are advantages, and which are location-bound and only provide an advantage at home.

The point of this discussion is that it is crucial to take a dynamic view of assets-asadvantages (and vice versa). If we are to look to the future of India's ability to spawn a new

\footnotetext{
${ }^{1}$ This is an oversimplification. For a discussion, see Eden (2010), Narula (2010, 2012)
} 
generation of Indian MNEs, and for extant Indian MNEs to continue to expand, the answer surely lies in the capacity of Indian firms to develop and sustain assets that are advantages, and upgrade those assets which no longer advantages.

\section{On the dual nature of $\mathrm{O}$ assets of DC MNEs}

Figure 1 specifies three classes of O assets (See Narula 2012, 2014 for a discussion). The first class of $\mathrm{O}$ assets are those recognised to be 'technology-type' assets, associated with proprietary knowledge content, whether embodied in intellectual property, or in technical personnel. They are most often associated with formal and informal innovation activities.

$* * *$ Figure 1 about here $* * *$

The second class are 'transaction-cost and organisational assets'. They are associated with knowledge that reduces intra-firm and market transaction costs, and represent, i. the expertise of managers to maintain efficient organisations (HRM, personnel, information systems, internal hierarchies); ii. knowledge of external markets; and iii. knowledge that permits them to transfer resources and transact efficiently with its various suppliers and customers. Indian firms have not demonstrated a capacity to organise cross-border activity especially efficiently, lacking, in most cases, the knowledge that comes from experience of being an MNE.

Nonetheless, this asset-class is also built upon experience and entrepreneurial abilities within the firm, and is closely associated with formal and informal institutions, both internal to the firm, and to the firm's environment. In the context of this paper, such assets can be locationspecific, because 'adverse conditions', such as incomplete supply chains, weak infrastructure, and unstable institutions may cause market failure/imperfections that require specific kinds of firm-specific routines to overcome them. Adverse conditions can act as a catalyst to develop specific assets that allow them to generate rents in specific conditions, or to develop internal assets to substitute for missing inputs.

Although some have argued that technology-type $\mathrm{O}$ assets are less necessary for DC MNEs (Contractor 2013, Ramamurti, 2009, 2012), this is contingent upon the capacity of firms to overcome weaknesses in one asset-class by strengths in other asset-classes. That is, a firm can overcome the absence of unique technologies by being able to organise its intra-firm transaction so efficiently that it generates a cost advantage from the latter which is greater than the disadvantage of the former. Alternatively, it can also finds ways to enhance its 
weaker $\mathrm{O}$ assets by creating entry barriers to other firms (e.g., through its knowledge of institutions) in a particular market.

This brings up the third class of assets, which are 'recombinative assets', which allow the firm to be to take a 'bundle' of assets needed to undertake a certain activity, and 'recombine' the assets to create a new 'bundle' by substituting other internal (or external) assets to achieve a similar outcome (Verbeke 2009, Hennart 2012). Recombination can be as elementary as the substitution of capital for labour (e.g., through automation), when establishing a subsidiary in country with a comparative disadvantage in labour. This idea of rebundling occurs in reverse as well, as $\mathrm{O}$ assets acquired abroad need to be modified to meet local needs. The concept is not dissimilar to that of "frugal innovation'2 which also implies recombining to adapt technologies to local conditions.

Nascent MNEs can often be successful in their initial investment forays abroad by recombining assets to achieve a cost advantage in specific locations. However, these are also easily eroded, because they are easily imitable by other DC MNEs, and by domestic firms (Madhok and Keyhani 2012). While cost advantages may be valuable for certain goods, they are not perfect substitutes for technology assets. Where costs are a small portion of their value, the benefit of being able to recombine to lower costs is marginal. Indeed, the failure of Tata's low-cost Nano in domestic and international markets illustrates this point effectively.

Figure 1 suggests that firms whose $\mathrm{O}$ advantages derive in greater part from recombinative assets as well as assets that derive specifically from firms' ability to profit from environmental imperfections give them an advantage that is not narrowly location-bound just to their home country but somewhat more generally to countries with similar locational characteristics (i.e., DC-specific). DC-specific assets are a sustainable advantage in other developing countries. They can be trade-supportive, helping activities that rely on inputs (which include skilled manpower) and intermediate goods from their home country, but also where the developing country affiliates engages in upstream and downstream activities associated with those in the home country. DC-specific assets matter less when venturing to in advanced economy markets, where $\mathrm{O}$ assets that are more knowledge-intensive (and less location-specific) matter more, such as those associated with technology-type $\mathrm{O}$ assets, or

\footnotetext{
${ }^{2}$ Although whether frugal innovation is fundamentally different to incremental innovations in products and processes is an open question.
} 
efficiencies that derive from efficient MNE organisation ${ }^{3}$. It helps explain why DC MNEs in low tech activities predominate in other developing countries, while their presence in the advanced economies is in more knowledge-intensive sectors.

\section{'Easy assets' through strategic asset-seeking M\&A.}

MNEs can acquire firms with $\mathrm{O}$ assets, which in principle provide the acquiring firms with ready-made networks, technological assets and managerial skills. This is certainly a more rapid option to establishing internal $\mathrm{R} \& \mathrm{D}$, and developing $\mathrm{O}$ assets 'organically'. However, firms cannot absorb outside knowledge unless they simultaneously invest in their own R\&D (Cantwell and Santangelo 1999). This is why the term 'asset-augmenting' is preferable to asset-seeking, because it clearly implies that firms must have existing assets that they can augment (Narula 2006). Besides, such assets is often context-specific, and must be 'unbundled' from its firm-specific context. Even in the most advanced MNEs, knowledge does not transmit freely, and the $\mathrm{O}$ assets of a parent are not necessarily available to all its subsidiaries, and vice versa (Narula 2014).

In practice, firms without substantial internal innovative and absorptive capacity are unlikely to be able to integrate acquired assets successfully. Besides, it is not entirely clear whether an $\mathrm{O}$ assets-through-acquisitions approach is cost-effective, with hubris and national pride affecting acquisition decisions rather than strategic or economic decisions (Hope et al 2011).

It is also not clear whether transaction cost-based $\mathrm{O}$ assets (such as organizational innovations, knowledge of markets, and so forth) acquired through M\&A can easily be internalised by the acquiring firm. Chittoor and Jena (2013) find that the majority of Indian acquisitions are not integrated into the parent company, with the acquired firm maintaining a high degree of organisational and managerial autonomy. Indeed, one of the reasons why Indian MNEs tend not to integrate their acquisitions may reflect the pragmatic realisation that they simply do not have the capacity to do so. Nonetheless, without such integration, DC MNEs do not benefit from the economies of common governance. In many ways, acquiring organisational assets through learning-by-doing within a joint venture are much better than acquisitions.

\footnotetext{
3 This distinction is an important one because it helps resolve the Ramamurti (2012)/Madhok and Kehyani (2012) dispute.
} 
Accessing the supplier and customer networks of an acquired affiliate is one thing; it is entirely another that the acquiring firm's parent company broadly benefits from the L assets of the host country. To generate such reverse knowledge flows the MNE subsidiary must be able to access the network of local firms and their associated knowledge infrastructure and then transfer it internally within the firm. That is, the subsidiary needs to be embedded within the local milieu as well as deeply integrated within the MNE network (Narula 2014), which is a challenge for even the most experienced MNEs. In general, benefits from exploiting L assets from host countries only become significant after MNEs have become substantially internationalized, and this is rarely true of DC MNEs.

\section{L assets and how they shape the DC MNE}

The $\mathrm{O}$ assets of firms are a function of the economic, social, and political milieu of the location where their strategic activities are based. L assets are about relevant complementary assets outside the boundaries of the MNE (or other firm actors) that are location-bound. L assets can be classified into three groups (Figure 2). They are in principle equally accessible to all firms that are physically or legally established in that location. But this remains 'in principle'. Access in practice can be restricted to incumbents (whether domestic or foreign). L assets may be made available differentially by the actions of governments (or private interest groups) that seek to restrict (or encourage) the activities of a particular group of actors by introducing barriers to specific $\mathrm{L}$ assets.

$* * *$ Figure 2 about here $* * *$

Economic development of any given nation and the growth of its firm sector are coevolutionary, meaning that a lesser developed economy will have a smaller and less competitive firm sector. By extension, such an economy will have fewer firms that possess $\mathrm{O}$ assets that will permit them to engage in outward direct investment, and many of the competitive advantages of domestic firms will be location-bound. Countries at different levels of economic development demonstrate a broadly similar economic structure (and L assets), and a similar degree of competitiveness of their domestic economic actors (and 
therefore its MNEs), given exogenous limitations due to their resource constraints or abundance (Dunning, 1981; Narula, 1996; Narula and Dunning, 2000, 2010).

Broadly speaking, countries move away from labour- and natural resource-intensive activity towards capital-intensive activity, and later to more knowledge-intensive activity (Dunning and Narula, 1996). Strong initial comparative advantages bias a country's economic structure towards specific industries, and thereby the specialisation of firms that utilise this initial advantage in future periods (Narula 1996). Firms tend to embark on a path of knowledge accumulation within the envelope of these $\mathrm{L}$ assets, and shape a distinct profile of national technological specialization (Cantwell 1989). The O assets of nascent MNEs therefore reflect the home country innovation systems, industrial structure and specialization (Narula, 1996, 2003). The $\mathrm{O}$ advantages - in terms of the three categories in figure 1 - tend also to coevolve around these 'pockets of excellence'.

Nascent MNEs do not always expand abroad because the $\mathrm{L}$ assets available to them are superior, but because they are able to derive $\mathrm{O}$ advantages from strengths and weaknesses of the L assets of their home country (Luo and Wang 2012). This is not novel concept - it returns us to the principle of private actors expand to take advantage of market imperfections and market failures which are caused by a variety of issues. For instance, poorly developed institutions may result in inefficient markets, which will propel entrepreneurs to create firms and hierarchies. This in turn might result in $\mathrm{O}$ advantages in operating countries in institutional voids. Other assets derive from strengths, say, in the availability of cheap skilled labour or specialised knowledge infrastructure. This allows them to develop new technologies, or modify existing technologies to meet specific local conditions. In other cases, shortages of particular essential natural resources at home may encourage firms to seek them abroad. Chinese and Indian MNEs have been noted for expanding in Africa to seek access to iron ore, petroleum, and other minerals. L assets are not singular and static, because they also interact and co-evolve with $\mathrm{O}$ assets. Indeed, the competitiveness of firms in particular sectors represents an L asset.

\section{The Dual Economy and India's MNEs}

Many developing countries demonstrate a 'dual economy', where a 'modern' set of industries in knowledge-intensive sectors have grown in parallel with 'traditional' agrarian and labourintensive sectors. India's outward FDI, and its L assets reflects its dual economy. 
The traditional sector: India has a revealed comparative advantage in exports in HecksherOhlin and Ricardian sectors (its largest export sectors are silk and cotton textiles, vegetable and animal fats, resins, gems and jewellery, carpets, leather, and commodity chemicals). These are low value-adding activities, relying on small-scale, labour-intensive and natural resource-intensive activities (Kumar and Gupta, 2008). These are sectors where firms have expanded abroad, mainly within buyer-dominated global value chains, and in which there is a fair amount of outward FDI, but which greatly depend upon Indian exports, or the acquisition of key inputs that need to be imported. Indeed, FDI in these resource-intensive sectors is often trade-supportive. There has been some manufacturing growth in areas such as auto components, metals and metal products, food and beverages, and chemicals. However, the firms in these sectors have largely remained in lower end of their respective value chains, which reflects a predominance of DC-specific $\mathrm{O}$ assets, and, simultaneously, a failure to upgrade to more knowledge-intensive sectors. These sectors have on the one hand benefitted from a large supply of cheap, unskilled labour at home, but on the other hand suffer from restrictions to domestic firm growth. Restrictive pre-liberalisation labour regulation hinders small firms from exploiting scale economies through firm growth. Indeed, there are incentives to stay in the informal micro-sector, a sector which has continued to grow, and may account for upwards of $90 \%$ of all manufacturing activity. The MNEs in these sectors are in general the large conglomerates or state-owned enterprises, both of which enjoy regulatory capture. They have, by and large, focused on investing in other developing countries with similar economic structure (and L assets) that they have at home.

The 'Modern' sector: India's MNEs in the 'modern', urban economy are better known abroad, concentrated within high-tech industries such as software, IT services and pharmaceuticals. They have relatively high levels of patenting and R\&D activity at home and have internationalised rapidly in advanced economies (Narula and Kodiyat 2013). At the same time, these sectors have seen a rapid growth in inward FDI: 77\% of all US patents granted to firms in India between 2008-12 were subsidiaries of foreign MNEs. Patenting by Indian firms remains highly concentrated by a few firms in a few sectors: only 48 private firms accounted for 688 patents over the same four-year period, and $90 \%$ of these were in pharmaceuticals and IT/software. This is indicative of important weaknesses in the longerterm competitiveness of the $\mathrm{O}$ assets of Indian firms. Although firms in these 'modern' sectors clearly have stronger technology-type $\mathrm{O}$ assets, they are still some distance from the technology frontier. Indian MNEs have lower R\&D intensities than the global average in 
their industry, explaining their expansion abroad in the lower-end of these sectors (NISTADS 2008). A majority of the M\&A abroad by Indian firms have been in pharma and software/IT, and have been both market-seeking and asset-augmenting. To some extent, the weaknesses in $\mathrm{L}$ assets have prompted their international expansion. On the one hand, poor intellectual property rights protection allowed certain Indian firms considerable leeway to build up technological assets by imitation. On the other, the poor knowledge infrastructure has limited domestic R\&D and internally generated innovation. Firms in both sectors have developed $\mathrm{O}$ assets by substituting private investments in training and $R \& D$ for limitations in public goods.

$\mathrm{L}$ assets at different points in time can act contrarily as a 'push' to internationalise and at a later stage, act to discourage expansion, and vice-versa. To take an example: Low cost skilled human capital formed an important L advantage for Indian IT services firms. Over the period $1980-2004$, over $60 \%$ of the total factor productivity growth in India came from the services sector (Das, et al, 2010). However, this cheap input has gradually dissipated. Workers in services reported a 150\% increase in wages between 2006 and 2010, three times the increase in the consumer price index (ILO 2013). Rising domestic wages have eroded that advantage and caused these firms to internationalise. However, they have not as yet developed the organisational expertise to properly integrate, coordinate, train and manage large numbers of non-Indian employees abroad. Therefore, Indian MNEs have relied greatly on utilising Indian workers in offshore locations, or selected destinations with similar institutional environments. Thus, while relying on technological $\mathrm{O}$ assets to expand abroad, they are also dependent upon DC-specific organisational assets to maintain these activities. They have preferred to establish their offshore activities in other developing countries, where they can use DCspecific L assets effectively. These firms' domestic activities has struggled to grow at quite the same pace they enjoyed during the first two decades of liberalisation, because of fundamental shortages of skilled (and affordable) manpower, both technical and managerial.

\section{Looking to the future: can India's MNEs continue to grow?}

Can India spawn a new generation of MNEs and sustain its existing ones? I have argued that answer lies in the capacity of Indian firms to develop and sustain assets that are advantages, and this is itself shaped to a greater extent by the L assets of the home country than by the strategy they choose. It is worth remembering that previous generations of DC MNEs (e.g., 
Korea, Taiwan, and Japan) continue to maintain strong home country embeddedness despite much greater international experience, and continue to be greatly shaped by the L assets of the home country (Rugman and Verbeke 2004).

It is also clear that India's MNE activity reflects its dual economy. A traditional sector relies on DC-specific O assets in scale- and natural resource-intensive sectors. Dependence on assets that focus on low costs, institutional voids and Indian exports as inputs is temporary, because competition from MNEs of other nationalities will surely erode such advantages over time. Without greater efforts to achieve economies of common governance and efficient MNE organisational structures (with the attendant advanced management capabilities), such loosely-integrated multi-domestic MNEs cannot survive greater competition.

The traditional sector also faces rising costs due to physical infrastructure bottlenecks. Unskilled labour is not the same thing as uneducated labour, and India has one of the highest illiteracy rates in the world. Bottlenecks in transportation and logistics infrastructure also act as a non-negligible cost. When private actors absorb the costs of what firms in other countries internalise from public goods of the home country, it raises the costs of all economic activity, and further dissipates low cost advantages and export markets.

The modern sector, by contrast, has been in knowledge-intensive, skills-dependent activities. Indian MNEs have expanded to advanced economies, based on a combination of competitive set of technological $\mathrm{O}$ assets, some with an incomplete set of organisational capabilities to function effectively as an MNE, or to sustainably grow through acquisitions. On the other hand, several of these MNEs are not really new at international activities, and nehave much like their advanced economy counterparts. They also have the advantage that many of these firms are part of large business groups that can afford to cross-subsidise their activities, and invest in acquisitions and $R \& D$.

By far the biggest challenge for both the modern and the traditional sectors come from the state of the knowledge infrastructure. Both need to move towards greater knowledge content and to higher value-added activity, but this requires investment in innovation, both by the firms and by the government. Interactive learning within an economy depends in large part on collaboration between firms, universities and public research organisations. The non-firm sector plays a dual role as providers of R\&D and as providers of human capital (Pavitt, 1984), which is essential for firms to build absorptive capacity. Where the knowledge infrastructure is weak, firms respond by creating internal alternatives to knowledge infrastructure. Under- 
qualified workers due to the deficiencies in the educational system require expensive inhouse training programmes, which is an additional cost to employers. Indeed, several large companies maintain considerable in-house training capacity for this reason (Modwel and Jelassi 2010). This is certainly an option for large firms, but it acts as a disincentive for smaller firms.

India has one of the lowest expenditures on higher education per student in Asia. There are considerable bottlenecks in the provision of vocational training, primary of which is simply an insufficient supply of graduates (National Knowledge Commission, 2009). The university sector also suffers from shortfalls. Although India produces more than 500,000 science and engineering (S\&E) graduates every year, a majority are of low quality. A 2011 study suggests that only $17.5 \%$ of the engineers were employable in the IT support services sector (Aspiring Minds, 2011). Indian demand for S\&E graduates has increased year-on-year for the last 10 years at approximately 20-25\%, but capacity increases have simply not kept up, and quality issues make many unemployable. The emigration of the best graduates from institutions such as the IIT's- possibly a third to half - to postgraduate programmes abroad, coupled with another third moving into management training, and creates further drain. This ultimately means that there are few highly skilled engineers available to Indian firms and foreign MNEs in India.

Expanding and improving tertiary education relies on investment. Almost half of the academic positions at the IIT's, India's top-tier technical universities, are vacant due to the lack of qualified PhD's, and in part due to the greater financial prospects in industry (and abroad) (Times of India 2013). Estimates of an overall 40,000 shortfall in qualified PhDlevel teaching positions may not be an exaggeration (Herstatt et al 2008). India produced fewer than 8000 doctorates in 2006 (NSF 2012), and there is no evidence that there has been much change since.

Another significant part of the knowledge infrastructure is the public research sector, which also provides important scientific input for $R \& D^{4}$. There is limited interaction between academic and research institutions and firms in India (D'Costa, 2009), partly because India's non-firm actors are run along administrative lines similar to government ministries, and suffers from considerable inefficiencies (NISTADS 2008). In addition, they are focused on

\footnotetext{
${ }^{4}$ A significant exception to this is the Council of Scientific and Industrial Research (CSIR), which coordinates 40 subsidiary centres. CSIR employs 4600 scientists and 8000 technical personnel. It awards over a 1000 doctorates annually, and is the single largest Indian US patent assignee in India.
} 
national priorities, with less than $10 \%$ of their resources being directed towards industrial $R \& D^{5}$.

This implies that Indian firms are at a disadvantage vis-à-vis those from other countries, where the knowledge infrastructure is part of the public good. The innovation system mitigates the uncertainty within the innovation process, both financial and technological (Arora 2011). Indian firms may find it effective to move their innovative activities abroad to access more efficient knowledge infrastructure, and indeed have done so.

India's institutions restrict the opportunities for smaller firms to overcome the liability of size, creating perverse opportunities for firms to remain small, and opt out of the formal sector. It is a fundamental paradox that India's informal sector has grown, despite its greater inefficiencies. Employment in the formal manufacturing industry was just over 5 million in 2007-08, only a marginal increase from 1990. Given the high minimum efficient scale in most knowledge-intensive and smithian industries, micro-firms have difficulty being competitive.

This is ultimately a result of India's labour legislation and pre-reform regulations that provides on the one hand special incentives to micro-enterprises by restricting entry of larger firms in certain sectors, while on the other hand, preventing smaller firms from growing. Large firms face restrictions to fire or replace workers, or declare bankruptcy. Small firms therefore prefer to be capital-intensive rather than labour-intensive to avoid the complexities of becoming larger, despite low labour costs. Large firms also tend to fragment outsourced activities to a considerable number of small units (perhaps because the smaller firms predominate) creating further inefficiencies. From a managerial perspective it means that there will be fewer new firms with $\mathrm{O}$ assets that can be exploited abroad, at least within the manufacturing sector. Despite improvements in India's intellectual property laws, patent protection remains weak, discouraging domestic and foreign firms from engaging in R\&D.

\section{Concluding remarks}

There is nothing inevitable about economic success and sustained growth. There is no evidence -as far as I know- that one race/nationality/community has genes that give them a

\footnotetext{
${ }^{5} 75 \%$ of India's public R\&D expenditures were directed towards atomic energy, space research, defence and agriculture. $15 \%$ was accounted for by biotechnology, IT, ocean development, non-conventional and renewable energy sources, medical research and environment and forests. (NISTADS 2008)
} 
greater or lesser natural capacity for intelligence, hard work and entrepreneurship. Capabilities that define success or failure are normally distributed in all populations. Success begets ex post rationalisations, as does failure. Likewise, there are no obvious differences between MNEs of different nationalities that do not either reflect the environment from which these firms emanate, or their experience in internationalising their activity.

By applying the dual economy concept originally proposed by Lewis (1954), it becomes simpler to appreciate and reconcile the contradictions of the typical emerging economy (not just India), and the fundamentally different types of economic activity that derive from each. This approach permits us to better understand why the 'new wave' DC MNE (with a focus on knowledge intensive sectors, and investments in advanced economies) continues to thrive in parallel with the 'old school' DC MNE that is labour-intensive and focuses on host countries with similar conditions (Gammeltoft et al 2010, Ramamurti 2009).

It will be remembered that Arthur Lewis was awarded the Nobel Prize not for the dual economy notion per se, but the proposition that long-run development in a country derives from and by the efficient reallocation of resources from (and by) the traditional economy to the modern economy. Applying these seminal ideas to understanding MNEs, we have revisited the $\mathrm{O}-\mathrm{L}$ interaction that underlies internationalisation, and sought to understand where the DC MNE's strength comes from, and highlighted the vulnerabilities of a growthby-acquisitions approach to sustaining DC MNEs' long term growth.

We have offered a caution against the 'euphoria' of internationalization of Indian firms, since there seem to be two parallel economies at play. India's successful (and more visible) MNEs represent the crème de la crème of Indian private enterprise, with considerable resources at their disposal. Those that have utilised these initial advantages judiciously to systematically upgrade their asset portfolio will surely continue to expand, although perhaps through organic means rather than M\&A. Indeed, many have developed traits of the 'mature' MNE, with professional management practices, planned structures, and formal R\&D.

Few of the smaller, less well-endowed Indian firms can afford to replicate the success of the large business-groups/conglomerates that have spawned the more successful Indian MNEs, given the high costs of utilising firm resources to overcome weaknesses in India's knowledge infrastructure. When such firms internationalise to overcome infrastructural bottlenecks at home, they 'hollow out' domestic capacity, further weakening the home country's L assets, constraining the competitiveness of subsequent generations of Indian firms. 


\section{References}

Arora, P. (2011). Innovation in Indian firms: Evidence from the pilot national innovation survey, ASCI Journal of Management, 41(1): 75-90.

Aspiring Minds (2011). National Employability Report: Engineering Graduates, Annual Report 2011, Gurgaon: Aspiring Minds.

Bhagwati, J., and Panagariya, A. (2012). India's Tryst with Destiny: Debunking Myths that Undermine Progress and Addressing New Challenges. Collins Business.

Cantwell, J. and Santangelo, G. D. (1999). The frontier of international technology networks: sourcing abroad the most highly tacit capabilities. Information Economics and Policy, 11(1): 101-123.

Cantwell, J. (1989). Technological Innovations and Multinational Corporations, Oxford: Basil Blackwell.

Chittoor, R. and Jena, D. (2013). Ranking India's transnational companies. ISB Insight, 11(1): 5-13.

Contractor, F. (2013). "Punching above their weight": The sources of competitive advantage for emerging market multinationals. International Journal of Emerging Markets. 8(4): 304328.

Cuervo-Cazurra, A. (2012). Extending theory by analysing developing country multinational companies: Solving the goldilocks debate. Global Strategy Journal, 2: 153-167.

Das, D., Erumban, A., Aggarwal, S., and Wadhwa, D. (2010). Total factor productivity growth in India in the reform period: A disaggregated sectoral analysis, Paper presented at World KLEMS Conference, Harvard University.

D'Costa, A. (2009). Extensive growth and innovation challenges in Bangalore, India. In G. Parayil and A. P. D'Costa (Eds.). The New Asian innovation dynamics: China and India in perspective: 79-109. New York: Palgrave Macmillan.

Dougherty, S., Herd, R., and Chalaux, T. (2009). What is holding back productivity growth in India? Recent micro evidence. OECD Journal: Economic Studies, 1: 1-22.

Drèze, J., and Sen, A. (2013). An Uncertain Glory: India and its Contradictions, London: Penguin.

Dunning, J. H. (1981). Explaining the international direct investment position of countries: Towards a dynamic or developmental approach. Weltwirtschaftliches Archiv, 119: 30-64.

Dunning, J. H., and Narula, R. (1996). Foreign direct investment and governments: Catalysts for economic restructuring. London: Routledge. 
Eden, L. and Dai, L. (2010). Rethinking the O in Dunning's OLI/Eclectic Paradigm. Multinational Business Review, 18(2): 13 - 34

Gammeltoft P, Barnard H, and Madhok, A. (2010). Emerging multinationals, emerging theory: macro- and micro-level perspectives. Journal of International Management, 16: 95101.

Hennart, J. (2012). Emerging market multinationals and the theory of the multinational enterprise. Global Strategy Journal, 2: 168-187.

Herstatt, C., Tiwari, R., Ernst, D., and Buse, S. (2008). India's national innovation system: Key elements and corporate perspectives. Working Paper no. 51, Institute of Technology and Innovation Management, Hamburg University of Technology.

Hope, O., Thomas, W., and Vyas, D. (2011). The cost of pride: Why do firms from developing countries bid higher? Journal of International Business Studies, 42: 128-151.

ILO. (2013). Global Wage Report 2012/13: Wages and equitable growth. Geneva: International Labour Organisation.

Kumar, R. and Gupta, A. S. (2008). Towards a competitive manufacturing sector, Indian Council for Research on International Economic Relations Working Paper, No. 203.

Kumaraswamy, A., Mudambi, R., Saranga, H., and Tripathy, A. (2012). Catch-up strategies in the Indian auto components industry: Domestic firms' responses to market liberalization. Journal of International Business Studies, 43: 368-395.

Lewis, W.A. (1954). Economic development with unlimited supply of labour. The Manchester School, 22: 139-191.

Luo, Y. and Wang, S. L. (2012), Foreign direct investment strategies by developing country multinationals: A diagnostic model for home country effects. Global Strategy Journal, 2(1): 244-261.

Madhok, A., and Keyhani, M. (2012). Acquisitions as entrepreneurship: Asymmetries, opportunities, and the internationalization of multinationals from emerging economies. Global Strategy Journal, 2(1): 26-40.

Meyer, K. E., Mudambi, R., and Narula, R. 2011. Multinational enterprises and local contexts: The opportunities and challenges of multiple embeddedness. Journal of Management Studies, 48(2): 235-252.

Modwel, S., and Jelassi, T. 2010. Productivity of India's Offshore Outsourcing Sector: Business-based Evidence, Sciences Po - Groupe de'Economie Mondiale Policy Brief, February.

Narula, R. (1996). Multinational investment and economic structure. London: Routledge. 
Narula, R. (2002). Innovation systems and 'inertia' in R\&D location: Norwegian firms and the role of systemic lock-in. Research Policy, 31: 795-816.

Narula, R. (2003). Globalisation and technology: Interdependence, innovation systems and industrial policy. Cambridge: Polity Press.

Narula (2006). Globalization, new ecologies, new zoologies, and the purported death of the eclectic paradigm. Asia Pacific Journal of Management, 23: 143-151.

Narula, R. (2010). Keeping the eclectic paradigm simple. Multinational Business Review, 18(2): $35-50$

Narula, R. (2012). Do we need different frameworks to explain infant MNEs from developing countries? Global Strategy Journal, 2: 188-204.

Narula, R. (2014). Exploring the paradox of competence-creating subsidiaries: balancing bandwidth and dispersion in MNEs. Long Range Planning. in press.

Narula, R., and Dunning, J. H. (2000). Industrial development, globalization and multinational enterprises: New realities for developing countries. Oxford Development Studies, 28(2): 141-167.

Narula, R., and Dunning, J. H. (2010). Multinational enterprises, development and globalisation: Some clarifications and a research agenda. Oxford Development Studies, 38(3): 263-287.

Narula, R., and Kodiyat, T. P. (2013). The growth of outward FDI and the competitiveness of the underlying economy: the case of India, UNU-MERIT Working Paper No. 2013-042.

Narula, R., and Santangelo, G. D. (2012). Location and collocation advantages in international innovation. Multinational Business Review, 20(1): 6-25.

National Knowledge Commission. (2009). Report to the nation 2006-2009. New Delhi: Government of India.

NISTADS. (2008). Industrial $R \& D$ in India: Contemporary scenario. India: Science and Technology. New Delhi: CSIR.

NSF. (2012). Science and Engineering Indicators. Arlington, VA: NSF.

Pavitt, K. (1984). Sectoral patterns of technical change: Towards a taxonomy and a theory. Research Policy, 13: 343-373.

Ramamurti, R. 2009. What have we learned about emerging market MNEs?. In R. Ramamurti \& J. V. Singh (Eds.). Emerging multinationals from emerging markets. Cambridge: Cambridge University Press.

Ramamurti, R. (2012). What is really different about emerging market multinationals? Global Strategy Journal, 2: 41-47. 
Rugman, A. 2009. Theoretical aspects of MNEs from emerging markets. In R. Ramamurti \& J. V. Singh (Eds.). Emerging multinationals from emerging markets: 42-63. Cambridge: Cambridge University Press.

Rugman, A. M., and Verbeke, A. (2004). A perspective on regional and global strategies of multinational enterprises. Journal of International Business Studies, 35(1): 3-18.

Singer, H. W. (1970). Dualism revisited: A new approach to the problems of the dual society in developing countries, Journal of Development Studies, 7(1): 60-75.

Times of India. 2013. 43\% of teaching slots in IITs lying unfilled. March 30.

Verbeke, A. (2009). International Business Strategy. Cambridge: Cambridge University Press 


\section{$O$ assets can be classified into three classes}

\section{Recombinative assets}

-Ability to substitute between asset classes

-knowledge to recombine/bundle with external assets

\begin{tabular}{l}
\hline 'Technology-type' \\
assets \\
-Intellectual property \\
(patents, etc.) \\
-Equipment \\
-Brands and \\
marketing \\
-Process \\
technologies
\end{tabular}

Technology assets (through formal and informal innovation) and transaction cost assets such as being able to manage crossborder organisations that permit economies of common governance are a function of $R \& D$ and multinationality - and therefore by definition not location-bound

\section{'Transaction-cost related} and organizational assets

-Knowledge to organise intra-firm activities and manage large organisations -Knowledge of external markets

-Knowledge of institutions and relational capabilities
DC-specific assets: more likely to be location-specific, because they are partly generated through experience. Thus they are specific to particular markets, or to certain types of markets with similar $\mathrm{L}$ assets/institutions.
MNEs with bias towards these assets in portfolio likely to succeed in advanced economies. Also likely to benefit from strategic asset augmentation because of higher absorptive capacity and undertake reverse knowledge transfer, gain economies of common governance and access to host country $\mathrm{L}$ assets.

Figure 1: $O$ advantages and Asset-classes of Developing Country MNEs 
Socio-economic and political milieu of the home country

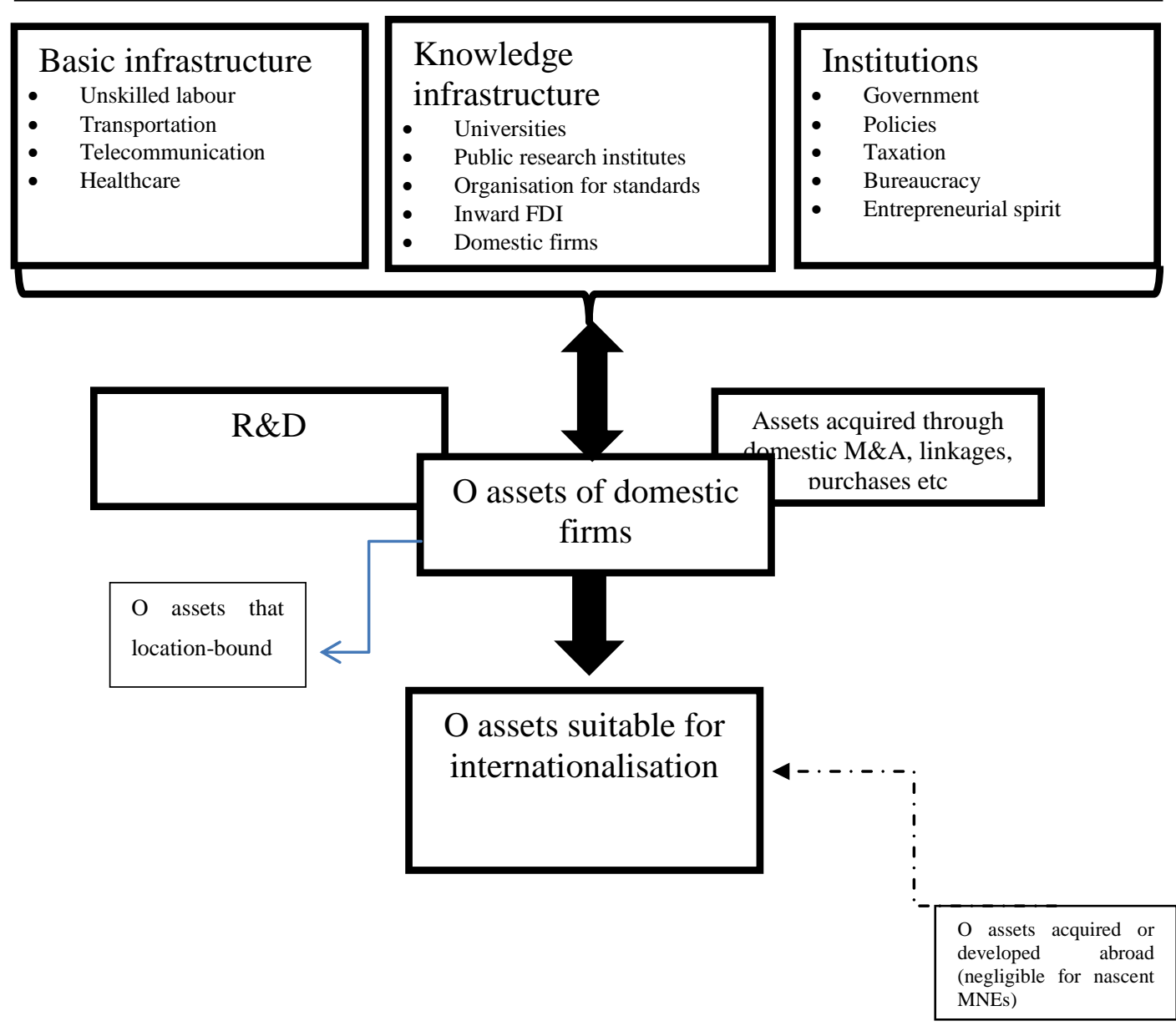

Figure 2: Relationship between $O$ assets and $L$ assets for nascent MNEs 